\title{
Factors to Consider in Selecting an Organisational Improvement Initiative: Survey Results
}

\author{
Musli Mohammad ${ }^{1, *}$, Maher Ali Hussein ${ }^{2}$ and Mohd Shahir Yahya ${ }^{3}$ \\ ${ }^{1}$ Industrial and Systems Engineering Focus Group, Department of Manufacturing and Industrial \\ Engineering, Faculty of Mechanical and Manufacturing Engineering, Universiti Tun Hussein Onn \\ Malaysia (UTHM), 86400, Batu Pahat, Johor, Malaysia \\ ${ }^{2}$ Al-Furat Al-Awsat Technical University - Technical Institute of Al-Mussaib, 54003, Kufa, Iraq \\ ${ }^{3}$ Department of Mechanical Engineering, Centre for Diploma Studies, Universiti Tun Hussein Onn \\ Malaysia (UTHM), 86400, Batu Pahat, Johor, Malaysia
}

\begin{abstract}
Organisations should select the appropriate improvement initiative that will fit with the context of organisation and provide value to the organisation. This paper presents 18 factors to be considered when selecting an organisational improvement initiative. Organisational improvement initiatives are approaches, management systems, tools and/or techniques that can be used for managing and improving organisations, such as Lean, ISO9001, Six Sigma and Improvement Team. A survey was conducted to identify the level of importance of these 18 factors as criteria for selecting an improvement initiative. Purposive sampling was used for this survey involving practitioners, managers, engineers, executives, consultants and/or academicians, who have been involved in the selection and/or implementation of organisational improvement initiatives in Malaysia. Two factors were rated as 'very high importance', which involve: (1) The ability to gain top management commitment and support to introduce and implement the initiative successfully, and (2) The initiative is aligned to the vision, mission and/or purpose of the organisation. All these factors can be adopted by the organisations as decision criteria to assist in the selection of the most appropriate improvement initiative based on rational decision making.
\end{abstract}

\section{Introduction}

There are many factors to consider in selecting an appropriate organisational improvement initiative, such as the current maturity level of an organisation, areas in which the initiatives are adopted, type or size of an organisation and the capabilities of its workforce [1-3]. 'Improvement initiatives' refers herein to approaches, management systems, tools and/or techniques that can be used for improving organisation and include, for example: Six

\footnotetext{
*Corresponding author: mmusli@uthm.edu.my
} 
Sigma, Lean, ISO9001, Business Continuity Management, and Environmental Management System [4-6]. Since every organisation is unique, there is no one best initiative that can solve all organisational problems. Each initiative also has its own purpose, strengths and limitations. The most appropriate initiative depends on the context in which it is adopted, rather than assumed to be universally applicable. Managers and/or leaders in the organisations should therefore consider all related factors before selecting the right initiative for the situation [4, 7-8]. Therefore, the objectives of this study are to identify factors that should be considered when selecting organisational improvement initiative and assess the level of importance of each factor for selecting the improvement initiative.

\section{Literature review}

Many existing literature have highlighted the importance of using contingency approach in managing organisation and understanding complex and dynamic situations, for instance Donaldson [9], Koontz and O'Donnell [10], Lawrence and Lorsch [11], and Sousa and Voss [12]. According to Kast and Rosenzweig [13], "the essence of contingency approach is that there is no one best way and that there is a middle ground between 'universal principles' and 'it all depends'. This approach recognises the complexity involved in managing modern organizations but uses the existing body of knowledge to relate environment and design, to match structure and technology, to integrate strategy and tactics, or to determine the appropriate degree of subordinate participation in decision making, given a specific situation".

Based on literature review, several contingency factors have been identified for the selection of improvement initiative which are as follow:

- Capability of the workforce to introduce and implement the initiative successfully [3, 14].

- $\quad$ Ability to gain top management commitment and support [1, 3, 14].

- Ability to allocate necessary resources to introduce and implement the initiatives successfully, such as funding and equipment $[8,15]$.

- $\quad$ Suit with the level of organisational excellence maturity $[2,16]$.

- The initiative is aligned to the vision, mission and/or purpose of the organisation [3, 14].

- The initiative is aligned to the direction, strategic plan and/or goals of the organisation $[3,14]$.

- The initiative will satisfy the requirements / expectations of the customers and other stakeholders [16].

- $\quad$ Suit with the organisational culture $[3,12,14]$.

- Suit with the external environment in which the organisations operate, which includes: political, economic, social, technological, legal and environmental factors [16-17].

- The initiative fits the sector / industry in which the organisation operates (e.g. private, public or non-profit) $[1-3,14]$.

- $\quad$ The initiative fits the size of the organisation (e.g. small, medium or large) $[1-3,14]$.

- The ability of the initiative to fit in with complement, integrate and/or to support other initiatives already in place, and might be used in the future $[8,15]$.

- $\quad$ Ability to implement the initiative easily in the organisation [4]

- Value for implementing the initiative (based on the cost benefit analysis, Return of Investment (ROI) analysis and/or payback analysis) [3, 8, 14, 18].

- Duration taken to obtain the value of implementing the initiative [16]. 
- Whether the initiative has been proven to provide value / benefit in other similar organisations [16].

- Popularity of the initiative (e.g. many other organisations are implementing the initiative) [3].

- Areas in which the initiative will be implemented (e.g. leadership and social responsibilities, planning and strategy, information, customer, process, and/or people) $[8,19]$.

\section{Research design and methodology}

Survey was used to collect data for this research. Self-administered questionnaire was selected as the survey instrument. The questionnaire was adapted from [4]. The questionnaire consists of an introductory page and four main sections. The introductory page provides the background to the researchers, describes the potential respondents, purposes of the survey, expected time taken to complete the survey, benefits of participating in the survey and the researchers contact information. The first section of the questionnaire covers general information about the respondent and respondents' organisation. The second section of the questionnaire obtains the respondents opinion on the level of importance of the factors that should be considered when selecting an appropriate improvement initiative. The third section requests respondents to evaluate the computer aided decision support tools for selecting organisational improvement initiative. The last section is to obtain the respondents opinions on strengths and weaknesses of the proposed computer aided decision support tool for selecting the organisational improvement initiative. This paper only presents results from Section 2 of the questionnaire.

Purposive sampling was used for this survey involving practitioners, managers, engineers, executives, consultants and/or academicians, who have involved in the selection and/or implementation of the organisational improvement initiatives. The reason for choosing this sample was due to the respondents' knowledge and/or experience in the selection and/or implementation of organisational improvement initiatives. Twenty three (23) respondents completed the questionnaire. $78.26 \%$ of total respondents have seven years or more than seven years of experience, which indicate that most of the respondents have vast experience in the area of quality, productivity and/or operational improvement. The respondents consist of managers, assistant managers, academicians, consultants, engineers, and vice president. 39\% of respondents are managers and assistant managers. Four percent of the total respondents were from organisations that had won Business Excellence or Quality Awards.

In section 2 of the questionnaire, the respondents were requested to indicate the level of importance of each factor that should be considered when selecting the improvement initiative. Eighteen factors were evaluated by the respondents. A six point likert scale was used to represent the levels of importance for each factor:

- Very high importance $=5$

- High importance $=4$

- Moderate importance $=3$

- Low importance $=2$

- Very low importance $=1$

- Not important $=0$ 
The returning of the completed questionnaire was taken as participants' consent to participate in this survey. Median was used to analyse the likert scale data because it is suitable for ordinal data and non-parametric analysis [20-21].

\section{Results and discussion}

The results were summarised in Table 1. Two factors were rated as 'very high importance' (Median $=5$ ). The factors are: (1) The ability to gain top management commitment and support to introduce and implement the initiative successfully, and (2) The initiative is aligned to the vision, mission and/or purpose of the organisation. Survey conducted by Mohammad [4] also found that 'the ability to gain top management commitment and support to introduce and implement the initiative successfully' was rated as 'very high importance'. Fourteen factors were rated as 'high importance' $($ Median $=4)$. The factors are:

- Capability of the workforce to introduce and implement the initiative successfully.

- Ability to allocate necessary resources to introduce and implement the initiative successfully (e.g. funding and equipment).

- The initiative is suitable for the level of the organisational excellence maturity.

- The initiative is aligned to the direction, strategic plan and/or goals of the organisation.

- The initiative will satisfy the requirements / expectations of the customers and other stakeholders.

- The initiative fits the organisation's culture.

- The initiative fits the sector/industry in which the organisation operates (e.g. private, public or non-profit).

- The initiative fits the size of the organisation (e.g. small, medium or large).

- The ability of the initiative to fit in with complement, to integrate and/or to support other initiatives already in place, and might be used in the future.

- Ability to implement the initiative easily in the organisation.

- Value for implementing the initiative (based on the cost benefit analysis, Return of Investment (ROI) analysis and/or payback analysis).

- Duration taken to obtain the value of implementing the initiative.

- Whether the initiative has been proven to provide value/benefit in other similar organisations.

- Areas in which the initiative will be implemented (e.g. leadership and social responsibilities, planning and strategy, information, customer, process, and/or people).

Subsequently, two factors were rated as 'moderate importance' (Median $=3$ ). The factors are: (1) The initiative is suitable for the external environment in which the organisation operates, which includes: political, economic, social, technological, legal and environmental factors, and (2) popularity of the initiative (e.g. many other organisations are implementing the initiative).

Table 1. Survey results on the levels of importance of each factor to be considered when selecting improvement initiative

\begin{tabular}{|c|c|c|c|c|c|}
\hline Factors & Valid & Missing & Median & Min & Max \\
\hline Q2.2 Ability to gain top management commitment and & 23 & 0 & 5 & 3 & 5 \\
\hline
\end{tabular}




\begin{tabular}{|c|c|c|c|c|c|}
\hline $\begin{array}{l}\text { support to introduce and implement the initiative } \\
\text { successfully. }\end{array}$ & & & & & \\
\hline $\begin{array}{l}\text { Q2.5 The initiative is aligned to the vision, mission } \\
\text { and/or purpose of the organisation }\end{array}$ & 23 & 0 & 5 & 3 & 5 \\
\hline $\begin{array}{l}\text { Q2.1 Capability of the workforce to introduce and } \\
\text { implement the initiative successfully }\end{array}$ & 23 & 0 & 4 & 3 & 5 \\
\hline $\begin{array}{l}\text { Q2.3 Ability to allocate the necessary resources to } \\
\text { introduce and implement the initiative successfully (e.g. } \\
\text { funding and equipment). }\end{array}$ & 23 & 0 & 4 & 3 & 5 \\
\hline $\begin{array}{l}\text { Q2.4 The initiative is suitable for the level of } \\
\text { organisational excellence maturity. }\end{array}$ & 23 & 0 & 4 & 3 & 5 \\
\hline $\begin{array}{l}\text { Q2.6 The initiative is aligned to the direction, strategic } \\
\text { plan and/or goals of the organisation. }\end{array}$ & 23 & 0 & 4 & 3 & 5 \\
\hline $\begin{array}{l}\text { Q2.7 The initiative will satisfy the requirements / } \\
\text { expectations of the customers and other stakeholders. }\end{array}$ & 22 & 1 & 4 & 3 & 5 \\
\hline Q2.8 The initiative fits the organisation's culture. & 23 & 0 & 4 & 2 & 5 \\
\hline $\begin{array}{l}\text { Q2.10 The initiative fits the sector / industry in which } \\
\text { the organisation operates (e.g. private, public or non- } \\
\text { profit). }\end{array}$ & 23 & 0 & 4 & 2 & 5 \\
\hline $\begin{array}{l}\text { Q2.11 The initiative fits the size of the organisation (e.g. } \\
\text { small, medium or large). }\end{array}$ & 23 & 0 & 4 & 2 & 5 \\
\hline $\begin{array}{l}\text { Q2.12 The ability of the initiative to fit in with } \\
\text { complement, integrates and/or to support other } \\
\text { initiatives already in place, and might be used in the } \\
\text { future. }\end{array}$ & 23 & 0 & 4 & 2 & 5 \\
\hline $\begin{array}{l}\text { Q2.13 Ability to implement the initiative easily in the } \\
\text { organisation }\end{array}$ & 23 & 0 & 4 & 3 & 5 \\
\hline $\begin{array}{l}\text { Q2.14 Value for implementing the initiative (based on } \\
\text { the cost benefit analysis, Return of Investment (ROI) } \\
\text { analysis and/or payback analysis). }\end{array}$ & 23 & 0 & 4 & 2 & 5 \\
\hline $\begin{array}{l}\text { Q2.15 Duration taken to obtain the value of } \\
\text { implementing the initiative. }\end{array}$ & 23 & 0 & 4 & 3 & 5 \\
\hline $\begin{array}{l}\text { Q2.16 Whether the initiative has been proven to provide } \\
\text { value / benefit in other similar organisations }\end{array}$ & 23 & 0 & 4 & 3 & 5 \\
\hline $\begin{array}{l}\text { Q2.18 Areas in which the initiative will be implemented } \\
\text { (e.g. leadership and social responsibilities, planning and } \\
\text { strategy, information, customer, process, and/or people). }\end{array}$ & 23 & 0 & 4 & 3 & 5 \\
\hline $\begin{array}{l}\text { Q2.9 The initiative is suitable for the external } \\
\text { environment in which the organisation operates, which } \\
\text { includes: political, economic, social, technological, legal } \\
\text { and environmental factors. }\end{array}$ & 23 & 0 & 3 & 2 & 5 \\
\hline $\begin{array}{l}\text { Q2.17 Popularity of the initiative (e.g. many other } \\
\text { organisations are implementing the initiative). }\end{array}$ & 23 & 0 & 3 & 1 & 4 \\
\hline
\end{tabular}

Remark:

5.0: $\quad$ Very high importance

4.0: $\quad$ High importance

3.0: $\quad$ Moderate importance

2.0: $\quad$ Low importance

1.0 : $\quad$ Very low importance 


\section{Conclusions}

This paper has presented 18 factors that should be considered when selecting organisational improvement initiative. Two factors were rated as 'very high importance' (Median $=5$ ), which involve: (1) The ability to gain top management commitment and support to introduce and implement the initiative successfully, and (2) The initiative is aligned to the vision, mission and/or purpose of the organisation. All the factors discussed in this paper can be adopted by the organisations as decision criteria to assist in the selection of the most appropriate improvement initiative based on rational decision making. The adoption of improvement initiatives requires time, resources, financial and knowledge. To avoid unnecessary waste and frustration as well as enhance confidence in implementation, the organisations should select the right initiative that will fit with the context of organisation and provide value to the organisation [4, 14]. Further research has been conducted to develop a decision support tool for selecting improvement initiative using the factors discussed in this paper.

\section{Acknowledgement}

The authors would like to thank Universiti Tun Hussein Onn Malaysia (UTHM) for funding this project under Multi-Disciplinary Research Grant (Vot. U092).

\section{References}

1. Benson, P.G., J.V. Saraph, and R.G. Schroeder, The effects of organisational context on quality management: An empirical investigation. Management Science, 37(9): p. 1107-1124, (1991)

2. Dahlgaard, J.J. and S.M. Dahlgaard-Park, The 4P quality strategy for breakthrough and sustainable development. European Quality, 10(4): p. 6-20, (2004)

3. Thawesaengskulthai, N., Selecting quality management and improvement initiatives: Case studies of industries in Thailand, Nottingham University Business School, University of Nottingham, (2007)

4. Mohammad, M., Development of a guidance model for the selection of organisational improvement initiatives, School of Engineering and Advanced Technology, Massey University: New Zealand, (2012)

5. Mohammad, M., Mann, R., Grigg, N., \& Wagner, J. P., Business Excellence Model: An overarching framework for managing and aligning multiple organisational improvement initiatives. Total Quality Management \& Business Excellence, 22(11): p. 1213-1236, (2011)

6. Van der Wiele, A., Van Iwaarden, J. D., Dale, B. G., \& Williams, A. R. T., Improvement approaches, in Managing Quality, B.G. Dale, A. Van der Weile, and J. Van Iwaarden, Editors, Blackwell Publishing: Malden, MA. p. 559-575, (2007)

7. Yahya, M.S., Mohammad, M., Omar, B., \& Ramly, E. F., A review on the selection of lean production tools and techniques. ARPN Journal of Engineering and Applied Sciences, 11(12): p. 7721-7727, (2016)

8. Mohammad, M., Mann, R., Grigg, N., \& Wagner, J. P., The right improvement initiative for the right situation: A contextual and systems approach, Proceedings of the 40th International Conference on Computers and Industrial Engineering, H. Ishii, 
et al., Editors., Institute of Electrical and Electronics Engineers (IEEE): Hyogo. p. 1-6, (2010)

9. Donaldson, L., The contingency theory of organizations, California, CA: Sage Publications, (2001)

10. Koontz, H. and C. O'Donnell, Management: A systems and contingency analysis of managerial functions, 6th ed., Tokyo: McGraw-Hill, (1976)

11. Lawrence, P.R. and J.W. Lorsch, Organization and environment: Managing differentiation and integration, Massachusetts: Harvard University Press, (1967)

12. Sousa, R. and C.A. Voss, Contingency research in operations management practices, Journal of Operations Management, 26: p. 697-713, (2008)

13. Kast, F.E. and J.E. Rosenzweig, Organization and management: A systems and contingency approach, 4th ed., New York, NY: McGraw-Hill, (1985)

14. Thawesaengskulthai, N. and J.D.T. Tannock, A decision aid for selecting improvement methodologies. International Journal of Production Research, 46(23): p. 6721-6737, (2008)

15. Dale, B.G., Tools and techniques: An overview, in Managing quality, B.G. Dale, T. Van der Wiele, and J. Van Iwaarden, Editors, Blackwell Publishing: Malden, MA. p. 336-381, (2007)

16. Mohammad, M., Mann, R., Grigg, N., \& Wagner, J. P., Selecting appropriate organisational improvement initiatives: A five steps approach, in Proceedings of the 15th International Conference on ISO and TQM S.K.M. Ho, Editor, Asia Pacific Business Excellence Standard Academy: Hong Kong. p. 1-6, (2011)

17. Capon, C., Understanding organisational context: Inside and outside organisations, 2nd ed., Harlow: Prentice Hall Financial Times, (2004)

18. Thawesaengskulthai, N. and J.D.T., Tannock, Pay-off selection criteria for quality and improvement initiatives. International Journal of Quality \& Reliability Management, 25(4): p. 366-382, (2008)

19. Saunders, M. and R. Mann, Business excellence tools: The tools used by companies at different stages of business excellence maturity, in Unpublished consultancy report, Centre for Organisational Excellence Research: Palmerston North, (2007)

20. Allen, I.E. and C.A. Seaman, Likert scales and data analyses. Quality Progress, 40(7): p. 64-65, (2007)

21. Jamieson, S., Likert scales: how to (ab) use them. Medical Education, 38(12): p. 1217$1218,(2004)$ 